\title{
Bid to block Yellowstone enzymes deal
}

[WASHINGTON] Public interest groups opposed to what they see as "commercialization" of US national parks are taking court action to try to block a deal between Yellowstone National Park and a Californian company that wants to search for and exploit enzymes from the park's hot springs.

In their lawsuit, filed last week in Washington DC, the groups allege that the Department of the Interior and the National Park Service have breached the 1986 Technology Transfer Act and various other statutes by signing the deal.

The agreement between Yellowstone and Diversa of San Diego, California, was announced by Vice-President Al Gore at Yellowstone's 125th birthday party last August, and is the first of its type in the United States. It is particularly important because of the vast scale and variety of Yellowstone's geothermal springs (see right) and the commercial success of the thermostable enzyme Taq polymerase. The enzyme is extracted from the bacterium Thermusaquaticus, which was found in hot springs at Yellowstone 30 years ago (see Nature 364, 2; 1993).

Taq polymerase is now used ubiquitously in the polymerase chain reaction for amplifying DNA. The patents for its use are held by Hoffman LaRoche and, although still subject to legal challenges, might eventually earn the Swiss drug corporation up to $\$ 1$ billion a year, none of which will go to Yellowstone.

Beth Burrows, president of the Edmonds Institute, a conservation group based in

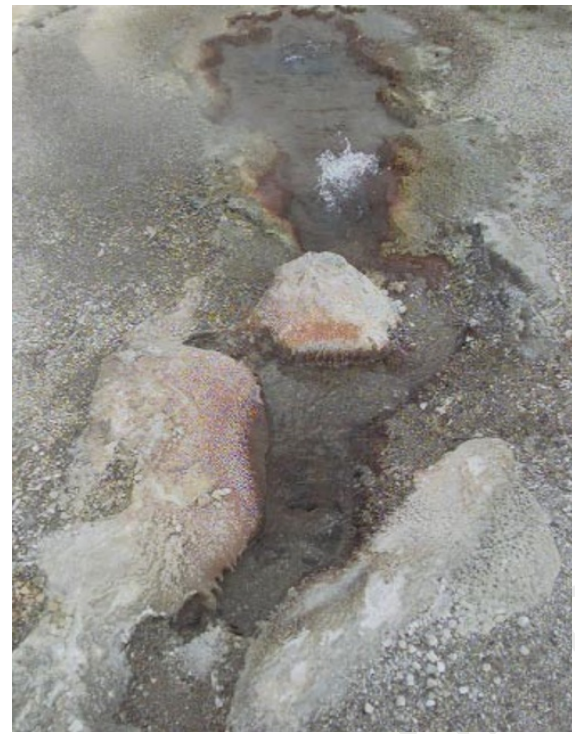

Trouble brewing: hot springs conflict is part of fight against national park 'commercialization'.

Washington state and one of the groups bringing the lawsuit, says: "We are objecting because there was no open, democratic procedure to negotiate the deal, or to decide if Yellowstone should be subject to such deals."

The lawsuit is also backed by the Alliance of the Wild Rockies, which claims to represent 3,500 users of the Yellowstone National Park, as well as by the International Center for Technology Assessment, which is a group in Washington DC that provides technical and legal support for environmental causes.
Joe Mendelson, a lawyer for the centre, says that Yellowstone is planning half a dozen more agreements of a similar nature, and that up to 20 could soon be negotiated by the national park system. But David Barna, a spokesman for the National Park Service, denies that other deals are being considered.

Barna says Yellowstone and Diversa will not delay the implementation of their agreement because of the lawsuit. "This has been a very open and public process," he says. "The only thing we're not making public is the size of the royalty payments. Diversa thinks such disclosure would harm its business interests."

The deal is a Co-operative Research and Development Agreement (CRADA) permitted under the Technology Transfer Act, which was written to assist public-private collaboration, in part by allowing government agencies to keep commercial data secret.

The public interest groups claim in their lawsuit that the deal is not a CRADA because no laboratory is involved, and natural resources - rather than technology — will be transferred. A congressional member of staff familiar with the law says it does permit the transfer of such resources. But opponents of the deal also claim that the agreement breaks various laws prohibiting commercial activities in national parks.

A spokeswoman for Diversa refused to comment on the court action. According to Mendelson, the district court of the District of Columbia will take several months to rule on the lawsuit.

\section{Plan for $\$ 100 \mathrm{~m}$ boost to Israeli biotech comes under threat}

[JERUSALEM] Concessions made by the Israeli Prime Minister, Benyamin Netanyahu, to ensure parliamentary approval of his budget have clouded the prospects for a US\$100 million venture capital fund that he promised Israel's biotechnology industry last September.

Yaron Zelekha, who heads the economic staff in the prime minister's office, says Netanyahu is solidly behind the initiative. But Zelekha admits that the shortfall in the national budget resulting from the deal in parliament is making it difficult to find the money, and that the chances of the fund being established are " $50: 50$ ".

According to Netanyahu's original announcement, about a fifth of the fund's capital would be provided by the government, the rest coming from private sources. Haim Aviv, who heads the National Israel Biotechnology Committee, an industry forum, says he is "still hopeful" that the fund will be established, despite the tight budget.

Aviv argues that government support for biotechnology, a fledgling but rapidly growing industry in Israel, is essential to enable it to expand. A survey submitted to the science ministry says the industry's sales

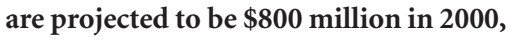
rising to $\$ 1.8$ billion in 2003 .

The survey, prepared by the Interdisciplinary Center for Technological Analysis and Forecasting at Tel Aviv University, points to a shortage of investment capital as the industry's most pressing problem. Senior executives in 28 Israeli companies in the fields of pharmaceuticals, diagnostics, agriculture and veterinary medicine said that a shortage of capital is the factor limiting their growth.

"Venture capital is extremely important for this industry, in relatively large sums," says Eliana Tapuhi, one of the researchers who conducted the survey. Government funds are an important part of the financial resources for these companies, the survey found.

Such funds come largely in the form of grants from the Ministry of Commerce and
Industry. The survey found that grants constitute 20 to 40 per cent of the funding for about one-third of the companies, and 40 to 60 per cent for 16 per cent of companies.

The survey also found an excess of qualified manpower for the industry. Tapuhi says that means there is untapped potential for expansion of biotechnology and related fields in Israel. Industry executives predicted a 105 per cent annual average growth in investment until 2000, falling to 51.7 per cent a year in 2001 to 2003.

"We need a significant injection of capital to realize our potential," says Aviv, suggesting that the prime minister's venture capital fund, although not huge, "can serve as a catalyst for the entire process". Foreign investors will be more willing to invest, he says, if they see that the government is putting money into the industry.

According to Zelekha, a decision on establishing the fund will be made within weeks. If it does not go through this year, "then we'll do it next year". Haim Watzman 